\title{
WILEY

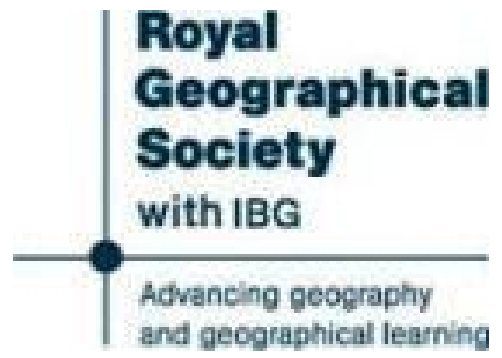

On the Annual Range of Temperature in the Surface Waters of the Ocean, and Its Relation to Other Oceanographical Phenomena: Discussion

Author(s): Wm. Wharton, Dr. Buchan, W. Leighton Jordan, Mill, George Murray and Dr. Gregory

Source: The Geographical Journal, Vol. 12, No. 2 (Aug., 1898), pp. 134-137

Published by: geographicalj

Stable URL: http://www.jstor.org/stable/1774460

Accessed: 27-06-2016 02:37 UTC

Your use of the JSTOR archive indicates your acceptance of the Terms \& Conditions of Use, available at

http://about.jstor.org/terms

JSTOR is a not-for-profit service that helps scholars, researchers, and students discover, use, and build upon a wide range of content in a trusted digital archive. We use information technology and tools to increase productivity and facilitate new forms of scholarship. For more information about JSTOR, please contact support@jstor.org.

Wiley, The Royal Geographical Society (with the Institute of British Geographers) are collaborating with JSTOR to digitize, preserve and extend access to The Geographical Journal 
Dr. Günther says the most striking character in the distribution of the shore-fishes of the southern temperate zone is the reappearance of types inhabiting the corresponding latitudes of the northern hemisphere, and not found in the intervening tropical zone. This interruption of the continuity in the geographical distribution of shore-fishes is exemplified by species as well as genera; for instance, Chimæra monstrosa, Galeus canis, Acanthias vulgaris, Acanthias blainvillii, Rhina squatina, Zeus faber, Lophius piscatorius, Centriscus scolopax, Engraulis encrasicholus, Clupea sprattus, Conger vulgaris. Instances, of genera are still more numerous : Cestracion, Spinax, Pristiophorus, Raja ; Callianthias, Polyprion, Histiopterus, Cantharus, Box, Girella, Pagellus, Chilodactylus, Sebastes, Aploactis, Agonus, Lepidopus, Cyttus, Psychrolutidæ, Notacanthus ; Lycodes, Merluccius, Lotella, Phycis, Motella ; Aulopus ; Urocampus, Solenognathus ; Myxine.

Many hypotheses have been advanced to account for this bipolarity in the distribution of marine organisms, and altogether the subject is a most interesting one, which will be discussed with greater detail in another communication.

Before the reading of the paper, the President said: I have to welcome here again Dr. John Murray. I may as well mention that the Royal Society last week had a very important meeting, when Dr. Murray read another most interesting paper on the Importance of the Results of Antarctic Exploration, and it was followed by a discussion of great importance and considerable weight, judging from the positions of those who took part in it, and which I believe and hope will have some effect on public opinion. I am sure the meeting will also welcome very heartily the presence this evening of a gallant companion of Dr. Nansen, Lieut. Johansen. He is only here for a few days amongst us, and we are delighted to see him.

After the reading of the paper, the following discussion took place :-

Admiral Sir Wu. Wharton: I suppose the President has called upon me because I have to do with the sea ; but my line of investigation is very considerably different from that of Dr. Murray. What Dr. Murray does he does very well,

Jahrbüchern, Abth. f. Syst., etc., Bd. ix. p. 585, 1896). Henderson, in his report on the Challenger Anomura, in describing Lithodes murrayi from the Kerguelen region, says it " is apparently most closely allied to Lithodes maia" (from the North Atlantic), "but the latter species is of large size, and the spines on the carapace are more numerous and more uniformly equal in size" (Henderson, Zool. Chall. Exp., pt. 69, p. 44). Henderson writes me that these very slight differences were the only ones he could df tect, and it seems evident that had the two specimens been taken from the same haul of the trawl, or from the same locality, they would never have been erected into two distinct species. Henderson writes me further that throughout the entire range of Crustacea there is no better illustration of bipolarity than that furnished by the Lithodidæ. See Chun, 'Die Beziehungen zwischen dem arktisehen und antarktischen Plankton.' Stuttgart: 1897. Ortmann, 'Grundzüge der marinen Tiergeoџraphie.' Jena: 1896. Pfeffer, 'Die niedere Thierwelt des antarktischen Ufergebietes,' Die Deutschen Expeditionen und ihre Ergebnisse (Die International Polarforschung), Bd. ii. p. 455. Berlin: 1890. Murray, Summary of Rerults Chall. Exp, p. 1459. 1894. 
and he has given us a most admirable lecture to-night. He has certainly enlarged my ideas very much on the effect of the changes of temperature in the water. He has done what has not been done before-constructed this map from extreme ranges. It has been taken in some cases from a small number of observations, but probably represents the main facts. He has shown us what a great effect these changes of temperature may have on life, and he has referred also to the great effect it has on meteorological conditions-the formation of cyclones. It has been well known for a long time that the great birthplace of gales are those areas that he has pointed out, where the changes of temperature are the greatest. I am not at all prepared to follow him in his speculations as to how the animals who live in the arctic and antarctic regions have managed to change their localities; but I think he has given us very good proof that the animals are practically identical, and the question of how that has come about, I suppose, will not be solved quite yet. It is a matter for further investigation. I do not think I shall add anything to your knowledge if I say anything more.

Dr. Buchan : In this communication Dr. Murray has made a notable adrance in oceanography. Several attempts have been previously made to show the range of the surface temperature of the ocean. But all these attempts have been simply to represent the difference in temperature between February and August, the coldest and warmest months respectively. It is, however, evident that such a range-temperature map of the surface waters of the oceans of the globe is singularly defective in showing the influence of temperature-changes on the living creatures with which the ocean everywhere teems. To do this it is altogether essential to reveal the absolute extremes of temperature to which these living creatures are exposed in the course of years. This is the problem which Dr. Murray has for years resolutely faced, and the map now hanging on the wall is the outcome of this great undertaking. It shows the difference between the absolutely bighest and the absolutely lowest temperatures hitherto observed in each $2^{\circ}$ square of the ocean, and the Royal Geographical Society is to be congratulated as being the medium of communicating this important investigation to the scientific world, which has been successfully carried out at no inconsiderable labour, time, and expense.

Mr. W. LEIGHTON JORDAN : What we have just heard from Dr. Murray evidently forms an admirable basis for a general discussion on the subject, and that has never yet been held since the Challenger returned, so I would suggest that the meeting be adjourned; we need not necessarily meet here, but I move that the meeting be adjourned in order that the discussion may be continued. It is too late now to have the discussion.

Dr. Murray : I should not be able to be present; I shall have to return to Scotland within two days.

Mr. Leighton Jordan: I am afraid it is rather late to start a discussion now-ten o'clock.

Dr. MILL: My only claim to speak is that, of all those in this audience, I am, perhaps, the one who has most enjoyed to-night's meeting. I have been associated with Dr. Murray for several years in practical oceanographical work, and it has been a wonder to me to see the way in which he has been able to fix upon those facts that were capable of the widest possible application, and to pass by others that were merely local. In his paper to-night he bas brought up a wealth of material suitable for discussion, but unfortunately there are very few-in fact, I feel there is no one-fully capable of discussing this question at the present time except Dr. Murray himself. That is one of the reasons why it is so desirable that we should have some more information, such as a new oceanographical expedition 


\section{THE ANNUAL RANGE OF TEMPERATURE IN THE SURFACE WATERS OF THE}

would collect. Then other people would have an opportunity of knowing something, and possibly of challenging Dr. Murray's opinions in consequence of the acquisition of fresh data.

Mr. George Murray: I can amply confirm the conclusion that Dr. Murray has arrived at with regard to bipolarity of organisms so far as they are concerned with the fora, both the littoral flora (those organisms that we call seaweeds) and also those that live far away from land. There is no doubt this bipolarity is especially striking in these organisms that live far away from land. Quite recently, however, with the help of Miss Barton, I made a minute examination of all the known littoral seaweeds in the arctic and antarctic regions, and we found a very nigh percentage of species in common; but this, however, is nothing to the community of type that exists among those minute organisms that live in the ocean. For example, the polar regions north and south are inhabited characteristically in the open ocean by diatoms, the temperate seas by Peridiniea and coccospheres, and the tropics by Peridinicæ, coccospheres, rbabdospheres, and other forms. Now, I had my conclusions (which were very likely somewhat cut and dry) a little upset last summer. You know the diatoms are characteristic of the polar sea, and find their finest development there, but yet they are always more abundant near land than they are in the open ocean ; in fact, by the use of a tow-net and a microscope, you would know almost as well as with a Thomson sounder when you are coming near land by the increase of the diatoms you get in your tow-net. I found in a traverse of the $A$ tlantic that I made last summer, and from observations made for me for a whole year between the Channel and the Caribbean sea by officers of the Royal Mail Steam Packet Company-I found from those observations that there were very few diatoms as soon as we got away from land, but when we got close to Barbados we got more, and rather more again in the Caribbean sea, and when we got to Panama we got an extraordinary number. The diatoms are abundant in Colon bay from August to February, from the two extremes of temperature (there is very little range of temperature there-from $81^{\circ}$ to $83^{\circ}$ ), and I venture to say they are quite as abundant there as they are in the arctic regions, or as they are in Loch Fyne, which, I believe, holds the record for diatoms in the number to the cubic inch, if I may put it that way. I should like to get an explanation from Dr. Murray; I should like to know whether temperature alone has much to do with this. It is quite true that in a place like Colon bay we have a very stable temperature, just as in the arctic and antarctic we have a very stable temperature. I must say the species we found in Colon bay were inseparable from the species we found in Loch Fyne. I should like to know whether the chemical constitution of the water has not something to do with this. One is rather apt to suspect this from the fact that diatoms are so abundant near land. I should like to know if these other factors have not something to do with this question of distribution, I mean besides temperature. I do not yield even to Dr. Mill in my estimate of the value of the facts brought before us by Dr. Murray; but I do plead for other factors besides temperature being taken into consideration, especially in dealing with such highly complex things as living organisms.

Dr. GreGory : I am glad of the opportunity as a biologist of expressing gratitude to Dr. Murray for this brilliantly original and suggestive paper, for it is on the researches of physicists that the biologists must rely for the explanation of the riddles of biological distribution. There are many points in the paper, I think, that will help biologists to explain some of those difficultics. During the last few years there has been a strong tendency to attribute all deposition of carbonate of lime from the sea to the direct action of life, but Dr. Murray's experiment of the precipitation of carbonate of lime from sea-water by the addition of ammonium 
carbonate may account for that inorganic precipitation of carbonate of lime which the microscope shows must take place. There were one or two points in which one could doubt whether Dr. Murray's explanations are of universal application. For example, with regard to the secretion of carbonate of lime either as calcite or as arragonite. We know that among mollusca living together on the same banks, some have shells of calcite and others of arragonite. In conclusion, I can only repeat my gratitude to Dr. Murray for this extremely suggestive paper.

Dr. Murray : I think that pelagic organisms which secrete silica are most abundant in those parts of the ocean where there is clayey matter in suspension, as in the arctic and antarctic seas, and in the West Pacific and off the mouths of large rivers. This, it seems to me, is more important than the temperature of the water. In discussing the causes which have led to a similarity in the fauna and flora of the two polar oceans, I may possibly bave been rather speculative, and have given my imagination too much rein. The interest of the subject must be my excuse.

The President : I am sure we are all very glad that Dr. Murray has given his imagination a little rein, but you must also have been impressed with the enormous labour that he undertook and has completed in giving the maximum and minimum ranges of temperature of the surface of the ocean all over the world in $2^{\circ}$ squares. It represents a great amount of labour, and from what we have heard to-night we know that it has not been labour in vain; that it has led to most interesting conclusions, and has shown the connection that exists between physical phenomena and biological phenomena, and we can have no doubt that Dr. Murray's most valuable chart will be permanently useful in the study of meteorology and of geographical distribution. I have, therefore, every confidence that the vote of thanks I now offer to Dr. Murray will be passed with acclamation.

\section{AN EXPLORATION IN 1897 OF SOME OF THE GLACIERS OF SPITSBERGEN.*}

\section{By Sir W. MARTIN CONWAY.}

LAST year (January 25) I had the honour of describing to this Society some of the results of an expedition which, in the year 1896, explored certain parts of the interior of the main island of Spitsbergen. Before that journey the interior was practically unknown. Monsieur Rabot had visited the Sassendal in 1892; and Herr Gustaf Nordenskiöld in 1890 had made the traverse over Torell glacier between two of the western bays, from Horn sound to the so-called Recherche bay of Bell sound. The result of our expedition was to show that a belt of the island bounded by Ice fjord on the north and Bell sound on the south, so far from being a region covered with ice, is practically open country, consisting of boggy hillsides and valleys, divided from one another by ranges of hills which have been carved out of a plateau. I was enabled to show, by examples, the various stages in the evolution of these hills, from their beginning in a plateau intersected by cañons to their final completion as sharp-edged, independent peaks. In no mountain region of

\footnotetext{
* Paper read at the Royal Geographical Society, March 14, 1898. Map, p. 224.
} 